УДК 371.134.007

DOI: $10.24144 / 2524-0609.2020 .47 .92-95$

\author{
Lema Olga \\ PhD student \\ Department of English Philology and Methodics of English Learning \\ Ternopil Volodymyr Hnatiuk National Pedagogical University \\ Ternopil, Ukraine \\ Karditsa, Greece \\ olina.lema2@gmail.com \\ ORCID ID: http://orcid.org/0000-0003-4453-8008 \\ Sokol Mariana \\ Doctor of Pedagogical Sciences, Professor \\ Department of Romanic-German Philology \\ Ternopil Volodymyr Hnatiuk National Pedagogical University \\ Ternopil, Ukraine \\ maryanasokol@ukr.net \\ ORCID ID: http://orcid.org/0000-0003-3876-026X \\ Rozlutska Galyna \\ Doctor of Pedagogical Sciences, Professor \\ Department of General Pedagogy and Pedagogy of Higher School \\ State University «Uzhhorod National University» \\ Uzhhorod, Ukraine \\ grozlutska@ukr.net \\ ORCID ID: http://orcid.org/0000-0001-9062-5466
}

\title{
PEDAGOGICAL ASPECTS OF PRINCIPAL'S ROLE AS A MANAGER AND LEADER IN GREECE SCHOOL UNIT
}

\begin{abstract}
The restructuring of the organization and administration of education, as an entity with a specific and complicated structure, which operates in a social educational space, supports its operation in human resources and focuses on the satisfaction of specific goals through the systematization of a set of actions, is a national state strategic choice for redefining our educational system in modern conditions. The purpose of this research is to highlight the high interest of the school unit as a learning community, a place of culture and civilization, but also an administrative organization institutionally hierarchical and organized. In particular, regarding the administration of a school unit as a process of coordinating people and activities to achieve proposed common goals, the role and importance of a principal, the responsibilities, duties and tasks assigned to it, as well as the scientific, pedagogical and administrative characteristics necessary for the successful and effective exercise of school leadership on this part. The way of exercising leadership, transfers into practice the personal theory of leadership of a leader, expresses the special managerial abilities and skills, reflects personality and general culture and frames every action and activity. This descriptive research is built mostly on theoretical methods: analysis of scientific works and publications for identifying the main tasks of the article. The study of the legal framework and the utilization of selected Greek and foreign language bibliography led to the distinction of main forms of leadership: authoritarian, lax, democratic leadership, distinguished on the basis of differentiated characteristics. The results of research converge on the emergence of democratic leadership as a necessary condition for the realization of the goal of quantitative and qualitative upgrading of the Greek educational system, according to the project of the modern pedagogical-scientific situation and the principle of democracy and justice.
\end{abstract}

Key words: school unit; administration; teachers; principal; pedagogical aspect.

Introduction. The school unit is treated as a formal organization with the task of achieving predetermined «objective» goals through specific organizational processes, which identify, coordinate and evaluate targeted collaborative work of its human factors in interdependence with each other and at the same time determine power to its members - linked by hierarchical relations with each other $[9, \mathrm{p} .78]$.

Of course, the school presents peculiarities and peculiarities in relation to other formal organizations, such as companies, for example, due to its dual character as an administrative and social institution at the same time. From its first capacity, it derives its institutionally determined function, its highly centralized character and its hierarchical organization on the basis of rules that regulate relations, define positions and define roles with specific rights and duties. The second, it defines its social function in the local and wider social structure in which it belongs and determines the form of its action and relations with other institutions in the context of its respective historical contexts, in relation to the general socio-political, cultural and economic conditions at the moment, but also under the influence of organized interests and pressure groups. On the other hand, teachers are not easily manageable resources, as, as it has been scientifically proven, they participate in the pedagogical work equipped with their own individual «utensil», scientific, pedagogical, ideological-political, which allows them in the context of their given relative autonomy from the educational structure - to intervene in their own way in the process of knowledge transfer, formation of attitudes and character shaping, performed by education $[3 ; 4]$.

The aim of the study is to define pedagogical aspects of principal's role as a manager and leader in Greece school unit. This descriptive research is built mostly on theoretical methods: analysis of scientific works and publications for identifying the main tasks of the article. The paper addresses ways of researching the 
pedagogy involved in building research methods competencies in the social sciences and defining the role of director pf the school as a manager and leader as well. The lack of explicit and shared pedagogy in this area make it particularly important that research is conducted to stimulate pedagogic culture, dialogue and development. The authors have been discussed the range of methods used in one study with the aim of teasing out pedagogical content knowledge, making implicit pedagogic knowledge more explicit and thereby malleable.

\section{Results and Discussion.}

School management - Role of a Principal. According to Law 1566/85, article 11, D, 1 «The principal of the school is particularly responsible for the smooth operation of the school, the coordination of school life, the observance of laws, circulars and official orders and the implementation of decisions of the teachers' association «He also participates «in the evaluation of the work of the school teachers and collaborates with the school counselors», while he carries out teaching work of limited weekly time depending on the size of the school and participates as chairman of the school council and the school committee, auxiliary bodies for ensuring the smooth operation of the school and the management of financial resources. These responsibilities, from which he derives his lack of power, remain without substantial changes until the first decade of the 21 st century, when in the context of the «revival» of the educational system and the reorganization of the educational administration, its role is upgraded and its power expands [8, p.43].

Management and Leadership. If we want to clarify the term «leadership», we stumble upon the absence of a specific and universally accepted definition of it, although it has not ceased to be a field of lively interest and intensive study by social scientists over the last two centuries. The lack of agreement between its scholars and researchers is probably due, on the one hand, to the fact that, as a multifactorial and multidimensional social phenomenon, it strongly resists a tight, unified and clear definition and skillfully escapes any attempt to (define) it, and on the other hand, in the perspective from which each scientist approaches it, the particular theoretical orientations on the basis of which he studies it and the parameters in which he emphasizes. If, however, «leadership» as a concept remains vague and confused, the same is not true of recognizing its importance, as a synthesis of phenomena of power, authority and influence [5, p.6] for the effective functioning of an organization. Leadership is, without a doubt, recognized as an important parameter of administrative work, which is exercised either «from above» or through dialectical interaction between «leader» and his subordinates and aims, mainly, at regulating the mentalities and attitudes of employees in relation to his conditions environment in which they operate $[1$, p.7] to achieve the maximum possible result. From the moment that «leadership» finds its conceptual and practical end in achieving specific goals of an organization by utilizing the human factor [6, p.48], it is obvious that a «leader» has a significant contribution to its quality improvement. educational project and the effective implementation of the goals of the school unit. This is because it (potentially) inspires, activates and coordinates - through a multilevel network of communication and relationships - the only living and most dynamic element in the organizational space with will, needs, habits and motivations, directing it to coherent, collaborative and conscious activities, which prescribe the effective achievement of educational goals $[9, \mathrm{p} .82]$ with positive implications for social life.

Leadership «style». The way of exercising leadership, transfers into practice the personal theory of lead- ership of the leader, expresses the special managerial abilities and skills that he has, reflects his personality and general culture and frames his every action and activity. It is, according to numerous studies and researches, international and Greek, one of the most important factors of the effective operation of an organization as -conditionally- it reduces the stress of the employees, binds them to the obligation of contribution and pushes them to active involvement in productive work with the aim of maximizing the efficiency of the organization in which they participate [7, p.105], attending specific actions and creating the appropriate climate to improve the efficiency of the organization [12, p.59] has a positive effect on creating cohesion of the employee team and increases satisfaction from their work. In short, it is the appropriate means of effectively expressing the «art of achieving goals through people» $[10, \mathrm{p} .125]$.

Leadership «styles» can be broadly divided into three categories: authoritarian leadership, democratic leadership, relaxed leadership.

1. Authoritarian leadership is a method of exercising power based on a clear bureaucratic hierarchy of relations between boss and subordinates, from which derive specific rules of communication and cooperation, articulated in the dipole «check / enforcement - obedience / submission». In this case, the supervisor undertakes exclusively the planning and organization of the organizational space and plays a dominant role in decision-making and in determining the actions of all team members, the non-execution of which entails penalties. He uses authoritarian behavior, accompanied by indirect or even direct intimidation, and demands the execution of his orders, often refusing to justify or justify his actions, while rejecting proposals that are not in line with his own decisions. Such a school leader degrades and de-professionalizes teachers, depriving them of the opportunity, on the one hand, to take initiatives to carry out their pedagogical work and, on the other hand, to participate in decision-making processes for the school development, while contributing to impersonal relationships they promote collaborative action to achieve predefined educational objectives. As a result, the school unit is unable to maximize its potential and, consequently, the school to respond effectively to the dynamics of the times and modern social needs, contributing to the «common interest» promotion.

2. Equally ineffective for education is the lax leadership, which is part of the liberating educational model, according to which the supervisor simply acts as a provider of information to his subordinates in the context of «community relations», which completely abolishes the hierarchical structure of the teacher, promote the equal participation of all those involved in decision-making and the execution of collective work without hierarchical differentiation and institutionalization of roles, but with increased sensitivity to their values and feelings. The acceptance of attitudes and roles that prevail in communities, promoted by this way of leadership, make it ideal for the effective work of a group of associates of the same degree, which presupposes meetings with a leader before formulating personal decisions and requires individual contributions to completion. collective work. It is not, however, effective in managing organizations that base their efficiency on the systemic interdependence of their members under the coordination, supervision and control of a leader and aim to achieve the maximum possible benefit for the largest possible number of individuals, as is the case with the educational system.

3. Having «rejected» authoritarian and lax power as ineffective for the quality upgrade of the school unit and the improvement of its productivity and efficiency 
with the criterion of promoting the «common good», we end up with the abduction of the democratic leadership, the which best corresponds to the characteristics of the school unit as a structural element of the wider educational system, understood as a «living organism» that operates in a specific social environment, with which it is connected by relationships of interdependence and interaction, and aims mainly to offer to the social total. In this context, the school unit specializes and adapts the general principles of operation of the educational system to the special conditions and situations it faces, while serving its goals through common procedures and activities of all teachers serving it, the effectiveness which a principal - «leader» undertakes to ensure by coordinating, supervising and controlling the produced collective work «from within». In this case, the decision-making for the execution of a collaborative project presupposes its active involvement in collaboration with the teaching staff, through which it is achieved - by the exchange of thoughts, ideas and opinions imbued with the will and the sense of responsibility for the effective execution of all of team members - clarifying the goals and aspirations of the school unit, cultivating sympathy and team spirit, and providing ethical incentives to maximize efforts to achieve the best possible outcome. Going from the level of decision-making to that of their implementation, the role of the democratic leader is catalytic in the discreet supervision of the work of the existing ones by providing instructions and suggestions for the smooth execution of the work and the coordination of the work in order to avoid any overlaps or omissions that reduce its effectiveness. These two activities require the manager to have experience and special skills in managing human resources, not only because in general human behavior is difficult to balance and orient in specific directions, but, mainly, because he often obeys impulses that have to do with the inner need for recognition and discrimination.

Conclusions and prospects for further research. The smooth and efficient school operation presupposes the ensuring of harmonious cooperation between the principal and the rest of the teaching staff through a democratic leadership, which, however, retains the right for itself. However, there is no program that would determine the level of successful professional activity of a principal, the directions and prospects of professional growth, strengthening of an adequate professional selfesteem, positive perception and professional comfort of a teacher. Such further international studies will allow not only to improve the quality of education, which directly depends on the activity of a prinvipal as a leader but will enable the administration of institutions to invite successful teachers, education managers and develop international mobility of academic staff.

\section{Список використаної літератури}

1. Buranda D. Human Factor Management. Athens: Self-published, 1984. P.7-19.

2. Chioti M.P. Human Relations at School. Athens: SELETE Publishing House, 1981. P.12-18.

3. Giroux H.A. Theory and Resistance in Education. A Pedagogy for the Opposition. Mass: Berginand Garvey, 1983. P.125-129.

4. Heliou M. Educational and Social Dynamics. Athens: Marchal, 1988. P.69-71.

5. Hemphill J.K. What is Leadership? The Canadian Administrator. 1968. Vol.8, 2. P.5-8.

6. Hersey P., Blanchard K. Management of Organizational Behavior: Utilizing Human Resources. Manhattan: Englewood Clifs, 1977. P.47-53.

7. Kanellopoulos Ch. Management. Effective Management. 2d ed. Athens: International Publishing, 1990. P.105-123.

8. Kouloumbaritsi A.X. The Administrative Framework in Primary and Secondary Education. Inspection of Pedagogical Issues. 2010. Vol. 13. P.43-54.

9. Saitis Ch. Organization and Administration of Education. Theory and action. Athens: Self-published, 1992. P.78-84.

10.Stoner J.A.F. Leader Management. New Jersey: Press, 1978. P.125-189.

11.Zachari E. Organization and Administration of Technical and Vocational Education. Athens: O.E.A.B., 1985. P.453-488.

12.Zavlanou M. Organizational behavior. Athens: Greek, 1998. P.59-68.

\section{References}

1. Buranda, D. (1984). Human Factor Management. Self-published.

2. Chioti, M.P. (1981). Human Relations at School. SELETE Publishing House.

3. Giroux, H.A. (1983). Theory and Resistance in Education. A Pedagogy for the Opposition. Berginand Garvey.

4. Heliou, M. (1988). Educational and Social Dynamics. Marchal.

5. Hemphill, J.K. (1968). What is Leadership? The Canadian Administrator, 8 (2), 5-8.

6. Hersey, P., \& Blanchard, K. (1977). Management of Organizational Behavior: Utilizing Human Resources. Englewood Clifs.

7. Kanellopoulos, Ch. (1990). Management. Effective Management. International Publishing.

8. Kouloumbaritsi, A.X. (2010). The Administrative Framework in Primary and Secondary Education. Inspection of Pedagogical Issues, 13, 43-54.

9. Saitis, Ch. (1992). Organization and Administration of Education. Theory and action. Self-published.

10.Stoner, J.A.F. (1978). Leader Management. Press.

11.Zachari, E. (1985). Organization and Administration of Technical and Vocational Education. O.E.A.B.

12.Zavlanou, M. (1998). Organizational behavior. Greek.

Стаття надійшла до редакції 01.11.2020 р. Стаття прийнята до друку 07.11.2020 р. 


\section{Лема Ольга}

аспірантка

кафедра англійської філології та методики навчання англійської мови

Тернопільський національний педагогічний університет імені Володимира Гнатюка

$$
\begin{gathered}
\text { м.Тернопіль, Україна } \\
\text { м.Кардітса, Греція }
\end{gathered}
$$

\section{Сокол Мар'яна Олегівна}

доктор педагогічних наук, професор кафедра романо-германської філології

Тернопільський національний педагогічний університет імені Володимира Гнатюка м.Тернопіль, Україна

\section{Розлуцька Галина Миколаївна}

доктор педагогічних наук

професор кафедри загальної педагогіки та педагогіки вищої школи

ДВНЗ «Ужгородський національний університет»

$$
\text { м. Ужгород, Україна }
$$

\section{ПЕДАГОГІЧНІ АСПЕКТИ РОЛІ ДИРЕКТОРА ЯК МЕНЕДЖЕРА ТА ЛІДЕРА У ШКІЛЬНОМУ ПІДРОЗДІЛІ}

Анотація. Реструктуризація організації та управління освітою як суб' єкта зі специфічною структурою, що функціонує в соціальному просторі, підтримує свою діяльність у людських ресурсах та зосереджується на задоволенні конкретних цілей через систематизацію комплексу дій, є національним стратегічним вибором щодо переосмислення освітньої системи в сучасних умовах. Мета дослідження полягає у з'ясуванні педагогічних аспектів ролі директора як менеджера та лідера шкільної одиниці у Греції. Навчально-виховний заклад є об'єктом професійної діяльності директора, як менеджера освіти, і виявляє свою сутність у формі соціально-педагогічної системи, яка є: за походженням - реальною; за субстанціональною ознакою - соціальною; за рівнем складності - багатофункціональною; за характером взаємодії з довкіллям - відкритою; за критерієм мінливості - розвиваючою і динамічною; за наявністю мети - цілеспрямованою; за мірою керованості - самокерованою. У відповідності до означених особливостей педагогічний менеджмент сучасного загальноосвітнього закладу постає, як комплекс принципів, методів, організаційних форм та технологічних прийомів управління процесом взаємодії керуючої (хто керує) і керованої (ким чи чим керують) підсистем, спрямований на досягнення його найвищої ефективності. Проаналізовано управління шкільним підрозділом як процесу координації людей та діяльності для досягнення запропонованих спільних цілей, ролі та значення директора, покладених на нього обов'язків та завдань, а також наукових, педагогічних та адміністративних характеристик необхідних для успішного та ефективного здійснення шкільного керівництва $з$ його боку.

Ключові слова: шкільний підрозділ; адміністрація; вчителі; директор; педагогічний аспект. 